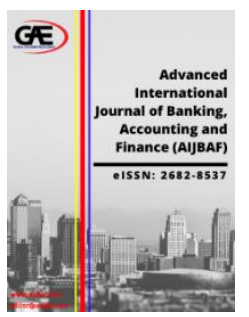

\author{
ADVANCED INTERNATIONAL JOURNAL OF \\ BANKING, ACCOUNTING AND FINANCE \\ (AIJBAF) \\ www.aijbaf.com
}

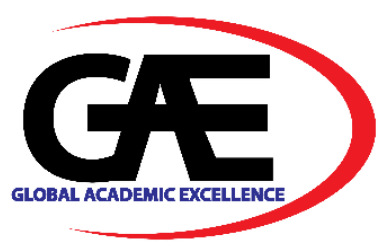

\title{
A CONCEPTUAL MODEL OF CREDIT SCORECARD IN PRODUCTIVE LOAN
}

\author{
Agiananta Rizyamesa ${ }^{1 *}$, Raden Aswin Rahadi ${ }^{2}$ \\ 1 School of Business and Management, Institut Teknologi Bandung, Indonesia \\ Email: agiananta_rizyamesa@sbm-itb.ac.id \\ 2 School of Business and Management, Institut Teknologi Bandung, Indonesia \\ Email: aswin.rahadi@sbm-itb.ac.id \\ Corresponding Author
}

\section{Article Info:}

\section{Article history:}

Received date:28.04.2020

Revised date: 12.08 .2020

Accepted date: 07.09.2020

Published date: 10.09 .2020

\section{To cite this document:}

Rizyamesa, A., \& Rahadi, R. A. (2020). A Conceptual Model of Credit Scorecard in Productive Loan. Advanced International Journal of Banking, Accounting, and Finance, 2 (4), 25-41.

DOI: $10.35631 /$ AIJBAF.24003.

\begin{abstract}
:
This study is aimed to discuss variables involved in credit scorecard assessment for granting agricultural credits. To get the variables, authors approached with the synthesizing method or Knowledge Synthesis Method from 25 papers related to the credit scorecard development in SMEs and Agriculture. This study used 5 C's of credit concept to group related variables and eliminated which are not. It is found that from the five aspects of 5C's, the character aspect consists of management, relationship, credit history, good corporate governance (GCG), behavior, and innovation. The capacity aspect consists of liquidity, profitability ratio, indebtedness degree, repayment history, activity ratio, financial growth, and expense ratio. The capital aspect consists of one indicator, namely capital structure. The conditioning aspect comprises of external factors of PESTEL, industry, and scope of a region in terms of monitoring. The collateral aspect consists of one indicator, which is a guarantee. All of these indicators will be a basic determinant of variables to appraise credit risk quality of a borrower in the agriculture sector. The limitation of this study is the scope limitation of conducting literature synthesize in particular papers which are related to appraising borrowers who are proposing productive loan, particularly in SMEs and the agriculture sector. The finding of this study will be useful for financial institutions that are responsible for developing assessments for borrower candidates in SMEs or the agriculture sector. Further process of research is eligible to be conducted, either qualitative or quantitative, in order to validate and improve the findings in this paper.
\end{abstract}

\section{Keywords:}

Credit Scorecard, SMEs, Agriculture, Productive Loan, Indicators, 5C's Of Credit 


\section{Introduction}

Financial inclusivity has been a critical aspect for the growth of economy. As defined in PP 82 2016 about National Strategic of Financial Inclusivity (SNKI), financial inclusivity is a condition that every member of society have an equal access towards formal and qualified financial services which on time, seamless, and secure with affordable price according to the needs and capacity in order to increase the wealth of society.

Indonesia has experienced significant improvement in financial inclusivity trends. Based on the Official Press Conference of Financial Service Authority (OJK) from 2017 to 2019, the Financial Inclusivity Index of Indonesia in 2013 was only 59,74\%, while Financial Literacy Index was $21,84 \%$. Up to 2019, the Financial Inclusivity and Financial Literacy has increased for $27,54 \%$ and $74,13 \%$ respectively.

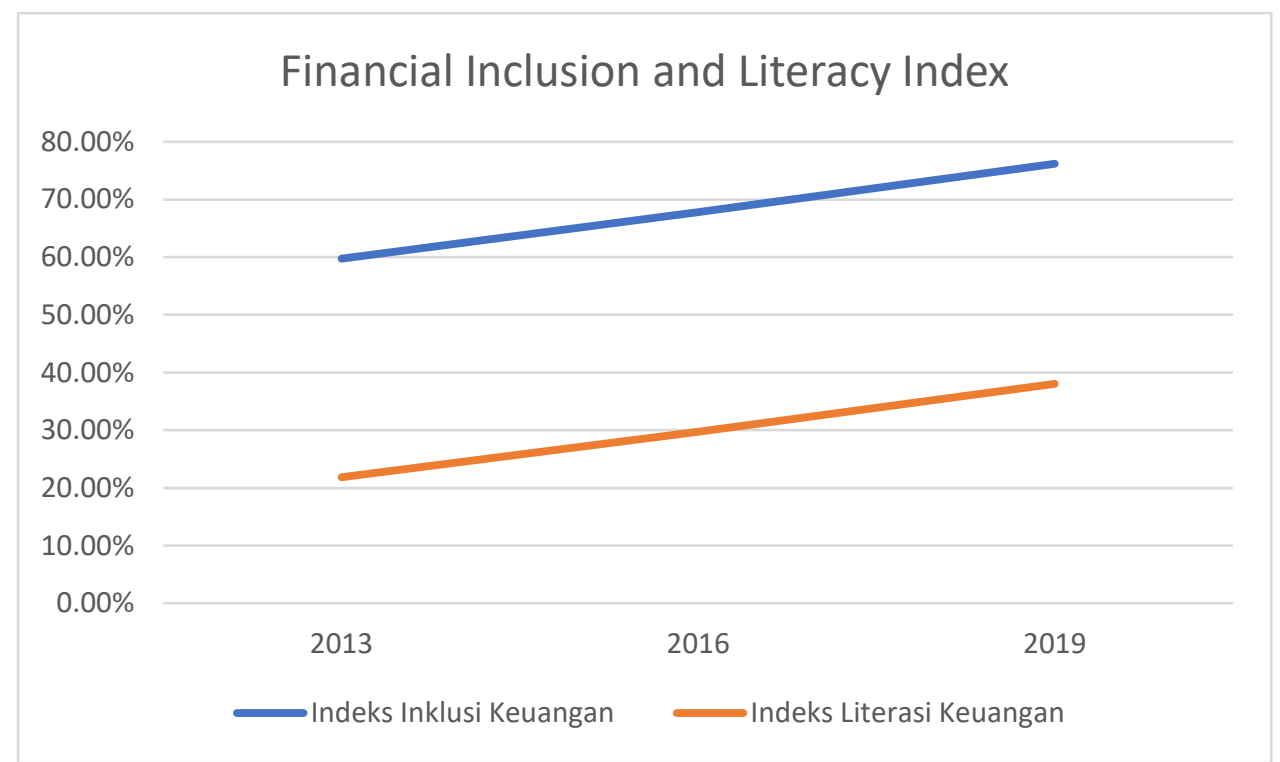

Figure 1: Financial Inclusion and Literacy Index Source: SP/07/DKNS/OJK/I/2017 \& SP/58/DHMS/OJK/XI/2019

The significant increase is not apart from the emerges of Fintech or Peer-to-peer (P2P) Lending platforms which mostly target the unbanked people in Indonesia. Fintech Lending contribute to the coverage expansion of Indonesia's "Credit Invisible" (PwC Indonesia, 2019). At least, $70 \%$ of the users of Fintech Lending comes from the unbanked people - including individuals and SMEs - which previously had no access to financial services.

One of the major contributors of unbanked people is agriculture sector. While $27,33 \%$ of workforce in Indonesia work in agriculture industry (Badan Pusat Statistik, 2019). Moreover, only $48,9 \%$ of workforce people in Indonesia have access to bank account, while the rest of them are still categorized as unbanked people (Demirguc-Kunt, Klapper, Singer, Ansar, \& Hess, 2017). Obviously, this specific target has become a huge potential market for P2P players. Within the 164 players which registered in OJK, at least three $\mathrm{P} 2 \mathrm{P}$ are focus their target market in agricultural sectors. 
A credit risk assessment process become an important process for $\mathrm{P} 2 \mathrm{P}$ in conducting their business process. P2P platforms do not only act as a marketplace that match borrowers' loan needs to the financing capital provided by lenders, they also act as a credit bureau to analyze a potential borrower's credit history and assess the risk of a loan (PwC Indonesia, 2019).

The purpose of this study is to find important variables need to be included as indicators in a credit scorecard in assessing creditworthiness of borrowers who propose productive loan, mainly in SMEs and agriculture sectors. The study uses 5C's of credit as the basic concept in determining the variables.

This study used knowledge synthesis method to gather variables from 25 of previous journals which discussed credit scoring in SMEs or agricultural studies. A knowledge synthesis summarizes all pertinent studies on a specific question, improves the understanding of inconsistencies in diverse evidence, and define future research agenda (Kastner, et al., 2012).

The variable gathering started from journal screening process. The journal screening consists of picking up literatures which discuss about credit scorecard development in productive loan, particularly the literatures which deepen their topics on Small and Medium Enterprises (SMEs) and agricultural sectors. The searched literatures include Agricultural Finance Review journals, Finance and Economics journals, Credit and Banking journals, and Management Research Review journals that are found to use both quantitative and qualitative methodology in developing credit scorecard which the variables are relevant with the principle of $5 \mathrm{C}$ 's of credit.

Afterwards, the variable gathering continued with variable selection and grouping process. This phase covers variable reviews and selection based on the 5 C's of credit principle. The variables which irrelevant with the principle were eliminated by authors. Following the selection process, authors classifying all of the relevant variables based on the characteristics of each variables and grouped those variables into relevant dimension within the $5 \mathrm{C}$ 's of credit principle.

A conceptual model is produced at the end of this paper. The conceptual model can be used for further studies or development of credit scorecard in productive loan. Furthermore, the findings from this paper will also essentials in improving quality of financial inclusion in Indonesia.

\section{Literature Review}

The literature review is divided into five sections based on the concept of $5 \mathrm{C}$ 's of credit, which are character, capacity, capital, condition, and collateral. Each of the section contains a further explanation about the variables that construct each section. A conceptual framework mapping will be available to indicate the research position of this study.

\section{Character}

Character aspect assessed for granting credits rests on traits such as honesty, reasonableness, acumen, industriousness, integrity, attitude, and commitment (Bhatt, 2012). Granting loan cannot be separated from character aspect, since it always related to human behavior either the borrowers are individual or a legal entity (which is represented by its board of commissioners and directors). This aspect appraises how borrowers would respond when others component of 
C's will turn bad. Therefore, character is put as the most prominent factor when banks or other financial institutions conduct preliminary assessment towards the borrower candidate.

Bhatt (2012) stated that character of borrowers depicted in two ways:

a. Disclosing of business affairs with the banker (loan grantor)

b. Use of funds for the purpose approved

Character aspect comprises of seven variables which include:

\section{Management Behavior}

Such as habit in banking (Bandyopadhyay, 2007) and transactional behavior records (credit history, incidents, integrity, and transparency) in obtaining credits (Caracota, Dimitriu, \& Dinu, 2010).

\section{Credit History}

Such as payment behavior of borrowers (Sbârcea, 2008), default rate (Ono, Hasumi, \& Hirata, 2014), borrowing from other financial institutions (Limsombunchai, Gan, \& Lee, 2005), repayment history (Ellinger, et al., 1991), amount of loan repaid and borrowed (Onyunecheya \& Ukoha, 2007).

\section{Management}

Such as management experience (Saygili, Saygili, \& Isik, 2019), management education (Limsombunchai, Gan, \& Lee, 2005), and the firm age (Ono, Hasumi, \& Hirata, 2014).

\section{Good Corporate Governance}

Includes business legality of the borrowers (Gool, Verbeke, Sercu, \& Baesens, 2011), audited or non-audited financial report (Ogler, 1970), and the documentation process within the operation (Ellinger, et al., 1991).

\section{Innovation}

The higher capability to make innovations, the lower credit risk of the borrowers will have (Zhang, He, \& Zhou, 2013).

\section{Loan Purpose}

Loan purpose means the main objective of borrowers in obtaining the credits (Gool, Verbeke, Sercu, \& Baesens, 2011).

\section{Relationship}

Which means the relationship related with how good relationship the borrowers with the bank or financial institutions which the borrowers borrowed the money (Ono, Hasumi, \& Hirata, 2014).

\section{Capacity}

Capacity does not only include legal status of borrower to enter into contract, rather it highlights the capability of business or person to generate sufficient cash flows to repay the loan (Bhatt, 2012). In productive loan context, providing a stable high profit in financial data is not sufficient enough to meet the capacity aspect. In fact, profit does not always reflect positive growth of cash. Sales or revenues for companies commonly comes on account which cause delay cash inflow to the company. In practice, it even needs to look deep into their bank 
statement, since it gives real picture of their financial condition. Furthermore, mitigation plan when the forecast does not go as planned also important to be analyzed for the loan grantors (Bhatt, 2012).

Based on journal synthesizing which has been conducted by authors, capacity aspect has seven variables involved to indicate the rate of credit risk, which are:

\section{Liquidity}

Such as current liquidity (Sbârcea, 2008), quick and current ratio (Zhang, He, \& Zhou, 2013), and net cash cycle (Hu \& Ansell, 2007).

\section{Profitability Ratio}

Such as profit margin ratios (Caracota, Dimitriu, \& Dinu, 2010), return on asset (ROA) (Zhang, He, \& Zhou, 2013), and return on equity (ROE) (Hu \& Ansell, 2007).

\section{Indebtedness Degree}

Such as coverage ratio (Min \& Lee, 2008), debt-to-EBITDA ratio (Altman, Esentato, \& Sabato, 2018), and debt-to-asset ratio (Ziari, leatham, \& Turvey, 1994).

\section{Repayment History}

Such as repayment punctuality (Ogler, 1970), clarity of payment source (Stover, Teas, \& Gardner, 1985), and repayment capacity (Ellinger, et al., 1991).

\section{Activity Ratio}

Such as receivable collection period (Caracota, Dimitriu, \& Dinu, 2010), total asset turnover (Zhang, He, \& Zhou, 2013), and payable turnover (Hu \& Ansell, 2007).

\section{Expense Ratio}

Expense ratio is a part of profitability measurement in a common-size income statement. A common-size income statement is an income statement in which each item is expressed as a percentage of sales (Gitman \& Zhutter, 2012). However, the expense ratio measures from the perspective of expense incurred within the financial period (Ellinger, et al., 1991).

\section{Financial Growth}

Which includes sales growth, EBIT growth, operating income growth, payroll growth (Hu \& Ansell, 2007), and earning trend (Ellinger, et al., 1991).

\section{Capital}

Bhatt (2017), stated in his research that capital aspect often referred as net worth it is the financial factor which provides the ability to overcome unanticipated losses. Capital also referred to the amount of capital contributed by the owner into the operation indicates his/her commitment running the business. Capital aspect has one variable which is involved to indicate the rate of credit risk, namely Capital Structure. Capital structure includes ratios which measure the structure of owner's fund compared with borrowed money involved in operating the business. The variables found are debt-to-equity ratio (Limsombunchai, Gan, \& Lee, 2005) \& equity-to-asset ratio (Ellinger, et al., 1991). 


\section{Condition}

Any business activity greatly impacted by surrounding conditions or commonly called as external factors. The external factors include competitive conditions, technology, demand for the product, regulations and economic changes (Bhatt, 2012). Further, it can be referred with PESTEL analysis concept. The dimensions consist of political, economic, social, technological, ecological, and legal aspect (Rothaermel, 2019). Even these aspects are uncontrolled by borrowers, it will affect either direct or indirect to the borrower's business activity. The conditions the borrower is operating under can have a major influence on credit quality (Baiden, 2011). Thus, external factors are inevitably in assessing loan proposal. Loan grantors may approach with different types of model to analyze the external factors.

Based on journal synthesizing which has been conducted by authors, condition aspect has three variables involved to indicate the rate of credit risk, which are:

\section{PESTEL}

Such as price volatility \& climate effects (Castro \& Garcia, 2014), pollution aspect \& demographic location of borrowers (Mittal, Gupta, \& Jain, 2011).

\section{Industry}

Relates with the conditions within the borrower's industries which might be different in each type of industry. There are numbers of journals that included industry variables such as Sbârcea (2008), Castro \& Garcia (2014), and Ono, Hasumi, \& Hirata, (2014).

\section{Region Scope}

Here is defined as the location distance between the borrower's business operation and the loan grantors branch or headquarter office (Onyunecheya \& Ukoha, 2007).

\section{Collateral}

Collateral refers to the asset or security which the borrower may charge or pledge against the loan (Bhatt, 2012). In a situation which borrowers cannot settle its loan, collateral will hold a vital role in solving the default. Collateral goods should be liquid, which mean that the collateral is easy to be sold and be converted to cash. Therefore, the easier the collateral be converted to cash, the better quality of collateral.

Based on journal synthesizing which has been conducted by authors, collateral aspect has one variable which is involved to indicate the rate of credit risk, namely Guarantee. This include the quality of guarantee (Sbârcea, 2008), presence of guarantor (Bandyopadhyay, 2007), and the value of guarantee (Amelie \& Allen M., 2001).

\section{Discussion}

Based on the literature review and knowledge synthesis from 25 previous studies which had been conducted by authors, there are five important major factors that should be included as the indicator of credit risk scorecard, which in line with the concept of 5C's of credit. The five major aspects - which consist of character, capacity, capital, condition, and collateral - are constructed from every variable which had been used in the previous. 
The first major factor is character. The character aspect assess' the behavior and the response of borrowers when other component of C's will turn bad. This aspect is derived into seven major variables which consist of behavior, credit history, management, good corporate governance (GCG), innovation, loan purpose, and relationship. The better character of borrower, the lower credit risk they would have.

Table 2: Character Variables (Author's Analysis)

\begin{tabular}{|l|l|l|}
\hline Character & Number of Each Variables & Number of Significant Variables \\
\hline Variables & 36 & 9 \\
\hline Management & 8 & 2 \\
\hline Credit history & 7 & 3 \\
\hline Relationship & 6 & 4 \\
\hline Behavior & 6 & 0 \\
\hline Loan purpose & 3 & 1 \\
\hline GCG & 1 & 1 \\
\hline Innovation & $\mathbf{6 7}$ & $\mathbf{2 0}$ \\
\hline Total & &
\end{tabular}

Author synthesized variables related with character dimension and its derivation. From table 1, character dimension has 67 variables and 20 variables (30\%) among them are classified as significant variables related with credit risk quality in each journal. Within the 25 journals, number of management variables dominated character dimension with 36 or $53 \%$ from the total variables. Along with the total number variables, the number of significant variables for character dimension also dominated by management with 9 variables or $13 \%$ from total character variable. This followed by behavior variable which has four variables which classified as significant variable in determining credit risk of borrower. 
Volume 2 Issue 4 (September 2020) PP. 25-41 DOI 10.35631/AIJBAF.24003

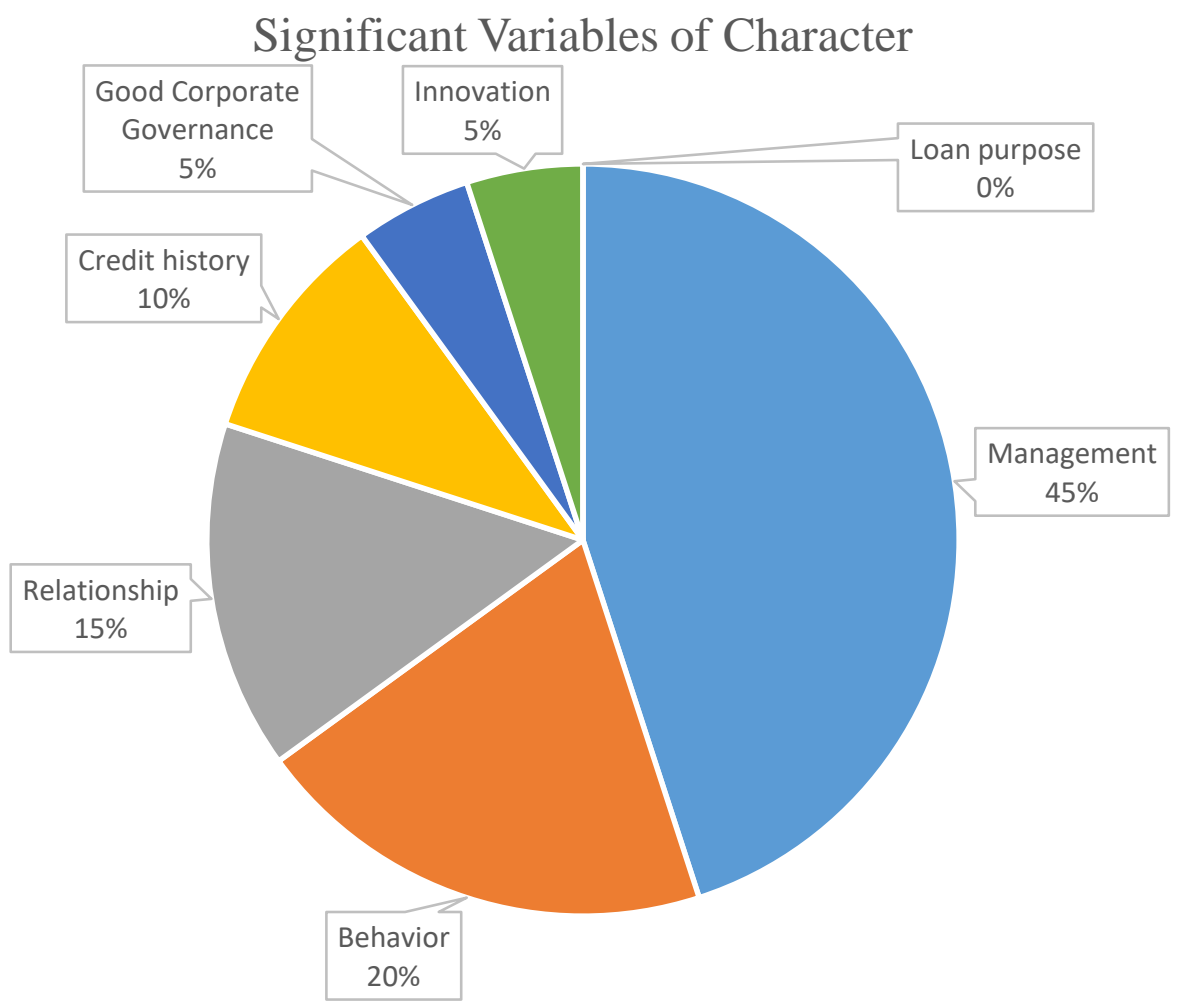

Figure 2: Significant Variables of Character (Author's Analysis)

Furthermore, authors analyzed the number of significant variables within the significant variables of character aspect. As figure 2 shows, from the total of 20 significant variables, management, behavior, and relationship dominate the number of significant variables with $45 \%, 25 \%$, and $15 \%$ respectively.

The second major factor is capacity. Capacity is the indicator of borrower's ability to repay their loan by their own cash. It is determined dominantly by financial ratios of the borrowers. Liquidity, profitability ratio, indebtedness degree, repayment history, activity ratio, expense ratio, and financial growth become main variables to construct the capacity aspect.

Table 2: Capacity Variables (Author Analysis)

\begin{tabular}{|l|l|l|}
\hline Capacity & Number of Each Variables & Number of Significant Variables \\
\hline Variables & 50 & 9 \\
\hline Liquidity & & \\
\hline $\begin{array}{l}\text { Indebtedness } \\
\text { Degree }\end{array}$ & 42 & 5 \\
\hline Profitability Ratio & 41 & 6 \\
\hline Activity Ratio & 13 & 3 \\
\hline Repayment History & 7 & 4 \\
\hline Financial Growth & 5 & 0 \\
\hline Expense Ratio & 3 & 0 \\
\hline Total & $\mathbf{1 6 1}$ & $\mathbf{2 7}$ \\
\hline
\end{tabular}


Author synthesized variables related with capacity dimension and its derivation. From table 2, capital dimension has 161 variables and 27 variables (17\%) among them are classified as significant variables related with credit risk quality in each journal. Within the 25 journals, number of liquidity sub-group variables dominated capacity dimension with 50 variables or $31 \%$ from total variables, and it followed with the indebtedness degree and profitability subgroup variables which consist of 42 and 41 variables respectively.

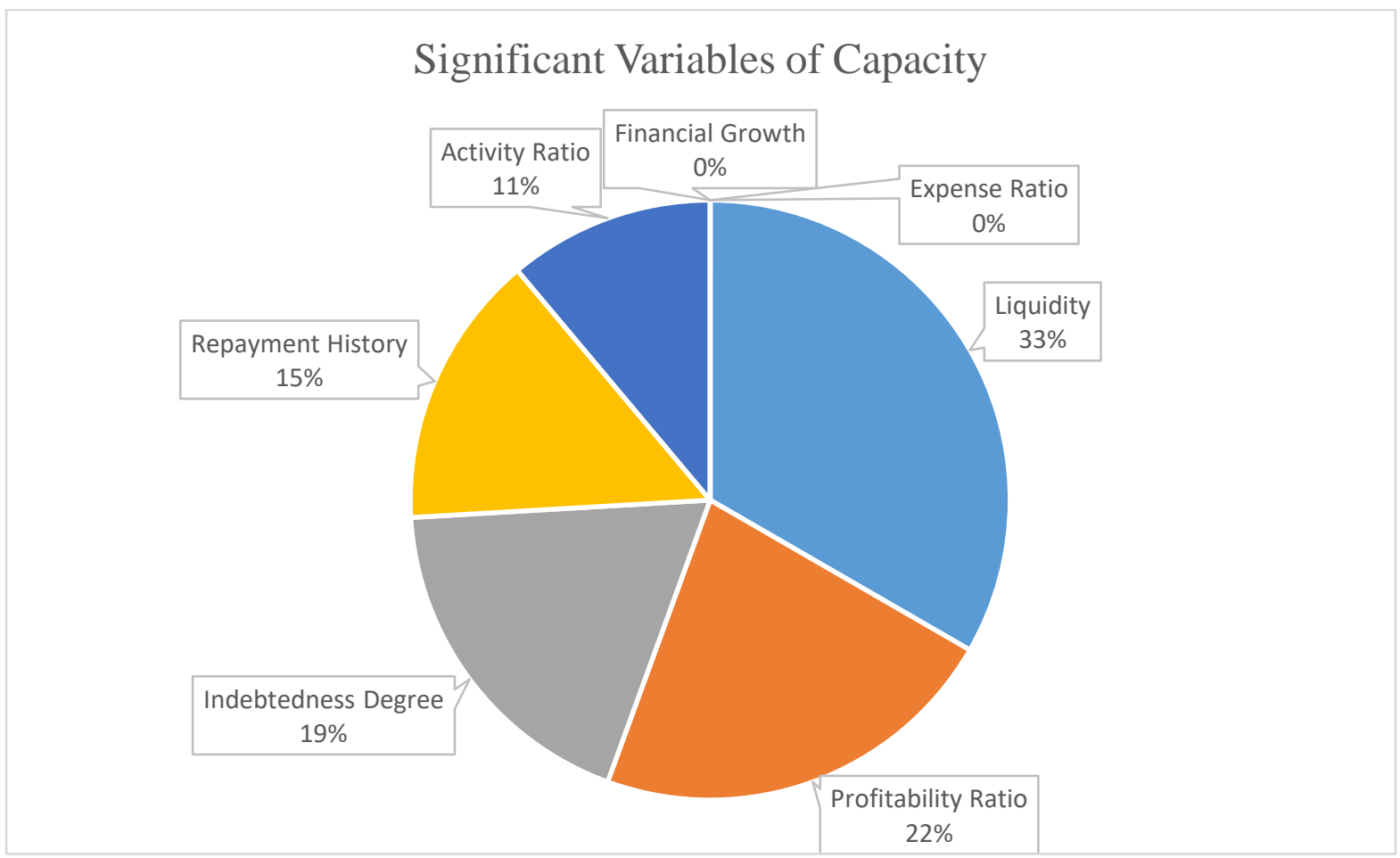

Figure 3: Significant Variables of Capacity (Author's Analysis)

Furthermore, author analyze the probability of significant variables among the variables provided related with capacity aspect. As figure 3 shows, from the total of 27 significant variables, liquidity, profitability, and indebtedness degree ratio dominate the significant variables for $33 \%, 22 \%$, and $19 \%$ respectively from the total variables. The rest of it consist of payment history and activity ratio have $15 \%$ and $11 \%$ respectively. While expense ratio and financial growth do not have any significant variables found in the 25 related studies.

The third major factor is capital. Capital aspect looks at the proportion of borrower's owned wealth which is contributed into the business operation compared with the proportion of money they borrowed. The rule of thumb the maximum of a lender is willing to contribute the money into the operation of borrowers is 75 percent compared to the owners 25 percent or debt-toworth ratio of three to one (Donaldson, 1986). Capital aspect consists of one type of variable which is capital structure. Capital structure itself comprise of ratios used by previous study that measure the proportion of owner's equity, such as debt-to-equity ratio and equity-to-asset ratio. 
Volume 2 Issue 4 (September 2020) PP. 25-41 DOI 10.35631/AIJBAF.24003

Table 3: Capital Variables (Author's Analysis)

\begin{tabular}{|l|l|l|}
\hline Capital & Number of Each Variables & Number of Significant Variables \\
\hline Variables & 20 & 8 \\
\hline Capital Structure & $\mathbf{2 0}$ & $\mathbf{8}$ \\
\hline
\end{tabular}

Author synthesized variables related with capital dimension and its derivation. From table 3, capital dimension, and the related sub-group, capital structure, has 20 variables and 8 variables or $40 \%$ among them are classified as significant variables related with credit risk quality in each journal.

The fourth major group is condition. Condition aspect consider external factors will influence the business activity of borrowers even though the factors might uncontrolled by borrowers. This aspect comprises of PESTEL analysis, industry, and region scope.

Table 4: Condition Variables (Author's Analysis)

\begin{tabular}{|l|l|l|}
\hline \multicolumn{3}{|l|}{ Condition } \\
\hline Variables & Number of Each Variables & Number of Significant Variables \\
\hline PESTEL & 26 & 9 \\
\hline Industry & 18 & 7 \\
\hline Region Scope & 4 & 2 \\
\hline Total & $\mathbf{4 8}$ & $\mathbf{1 8}$ \\
\hline
\end{tabular}

Author synthesized variables related with condition dimension and its derivation. From table 4, condition dimension has 48 variables and 18 variables, or 37,5\% among them are classified as significant variables related with credit risk quality in each journal. Within the 25 journals, number of PESTEL sub-group variables dominated condition dimension with 26 variables or $54 \%$ from total variables, and it followed with the industry variables which consist of 18 variables or $37,5 \%$ of total variables. This shows that to determine borrower's condition, analyzing PESTEL borrowers is the most common measurement. 
Volume 2 Issue 4 (September 2020) PP. 25-41 DOI 10.35631/AIJBAF.24003

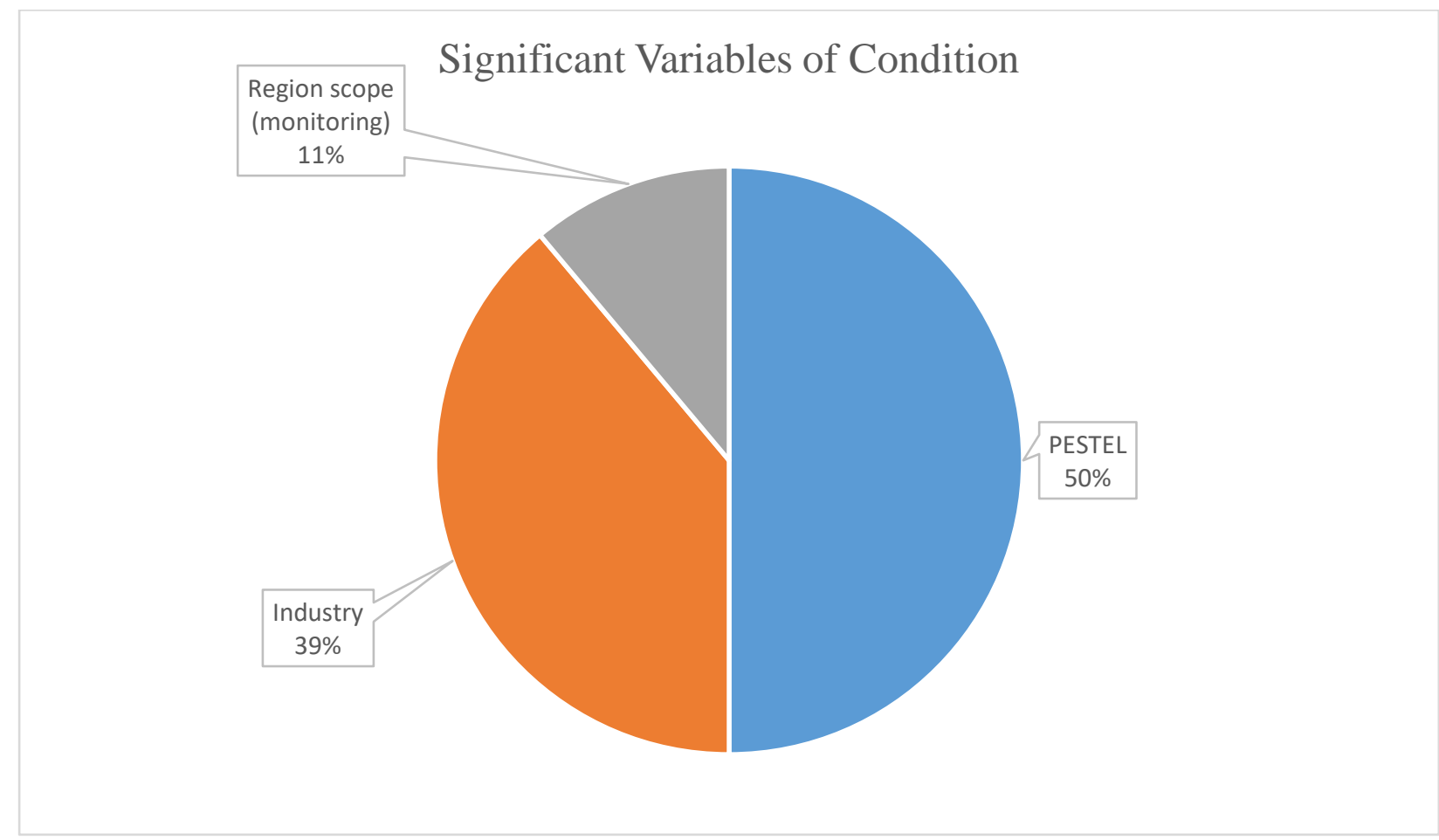

Figure 4: Significant Variables of Condition (Author's Analysis)

Furthermore, from the total of 18 significant variables $50 \%$ of them is PESTEL variable and considered has significances with quality of credit risk. As it showed in figure 4 PESTEL is followed by industry and region scope variables which contribute $39 \%$ and $11 \%$ respectively from the total significant variables.

The last major factor in determining credit risk of borrowers is collateral. Even though collateral might not be counted as the borrower's resource to pay their loan, it will perform as a cushion when the other C's do not perform well. Collateral should be liquid or easy to be converted to cash.

Table 5: Collateral Variables (Author's Analysis)

\begin{tabular}{|l|l|l|}
\hline Collateral & Number of Each Variables & Number of Significant Variables \\
\hline Variables & 16 & 2 \\
\hline Guarantee & $\mathbf{1 6}$ & $\mathbf{2}$ \\
\hline Total & &
\end{tabular}

Author synthesized variables related with collateral dimension and its derivation. From table 5 , collateral dimension, and the related sub-group, guarantee, has 20 variables and 8 variables or $12 \%$ among them are classified as significant variables related with credit risk quality in each journal. 
Volume 2 Issue 4 (September 2020) PP. 25-41 DOI 10.35631/AIJBAF.24003

Table 6: Journal Studied for the Synthesized Literatures

\begin{tabular}{|c|c|c|c|}
\hline Author(s) & Data Set & Methodology & 5 C's Dimensions \\
\hline Sbârcea (2008) & $\begin{array}{l}\text { Agriculture granted } \\
\text { loan in 2006, 2007, } \\
2008 \text { during the } \\
\text { Farmer Programs } \\
\text { which developed by } \\
\text { several banks in } \\
\text { Romania }\end{array}$ & $\begin{array}{l}\text { Empirical analysis } \\
\text { towards the credit } \\
\text { risk outlook during } \\
\text { the Farmer Programs } \\
(2006-2008)\end{array}$ & $\begin{array}{l}\text { Character, capacity, } \\
\text { capital, collateral, } \\
\text { condition }\end{array}$ \\
\hline $\begin{array}{l}\text { Castro and Garcia } \\
\text { (2014) }\end{array}$ & $\begin{array}{l}\text { Monthly data from } \\
\text { December } 2005 \text { to } \\
\text { November } 2012 \text { of } \\
\text { exposures and } \\
\text { default loans in } \\
\text { biggest rural bank in } \\
\text { Colombia }\end{array}$ & $\begin{array}{l}\text { Generalized Linear } \\
\text { Model (GLM) based } \\
\text { on a structural } \\
\text { default risk model }\end{array}$ & Condition \\
\hline $\begin{array}{l}\text { Mittal, Gupta, \& } \\
\text { Jain (2011) }\end{array}$ & $\begin{array}{l}2,864 \text { India micro } \\
\text { enterprises that had } \\
\text { bank loan between } \\
31 \text { January } 2007 \text { and } \\
31 \text { January } 2009\end{array}$ & $\begin{array}{l}\text { Neural Network - } \\
\text { Multilayer } \\
\text { perceptron (MLPs) } \\
\text { procedure }\end{array}$ & $\begin{array}{l}\text { Capacity, condition, } \\
\text { collateral }\end{array}$ \\
\hline $\begin{array}{l}\text { Saygili, Saygili, \& } \\
\text { Isik (2019) }\end{array}$ & $\begin{array}{l}125 \text { SMEs operating } \\
\text { in Turkey }\end{array}$ & Regression Analysis & $\begin{array}{l}\text { Character \& } \\
\text { capacity }\end{array}$ \\
\hline $\begin{array}{l}\text { Budimir \& Aralica } \\
\text { (2013) }\end{array}$ & $\begin{array}{l}\text { Croatian crafts } \\
\text { industry which was } \\
\text { financed in the } \\
\text { beginning period of } \\
\text { financial crisis } \\
\text { (2008-2010) and } \\
\text { over the five year of } \\
\text { the ongoing } \\
\text { financial crisis } \\
\text { (2008-2013) }\end{array}$ & Logistic Regression & $\begin{array}{l}\text { Character, capacity, } \\
\text { capital, \& condition }\end{array}$ \\
\hline Orgler (1970) & $\begin{array}{l}75 \text { bad loans \& } 225 \\
\text { good loans of } \\
\text { several banks in East } \\
\text { Coast states, United } \\
\text { States }\end{array}$ & $\begin{array}{l}\text { Multivariate } \\
\text { Regression Analysis }\end{array}$ & $\begin{array}{l}\text { Character \& } \\
\text { capacity }\end{array}$ \\
\hline $\begin{array}{l}\text { Caracota, Dimitriu, } \\
\text { \& Dinu (2010) }\end{array}$ & $\begin{array}{l}\text { Financial } \\
\text { information (2007- } \\
2008) \text { of } 113 \\
\text { companies which } \\
\text { funded by bank in } \\
\text { Romania }\end{array}$ & Logistic Regression & Capacity \\
\hline $\begin{array}{l}\text { Gool, Verbeke, } \\
\text { Sercu, \& Baesens } \\
(2011)\end{array}$ & $\begin{array}{l}\text { Bosnia- } \\
\text { Herzegovinian } \\
\text { microlenders from }\end{array}$ & Logistic Regression & $\begin{array}{l}\text { Character, capacity, } \\
\text { capital, \& condition }\end{array}$ \\
\hline
\end{tabular}


Volume 2 Issue 4 (September 2020) PP. 25-41 DOI 10.35631/AIJBAF.24003

\begin{tabular}{|c|c|c|c|}
\hline Author(s) & Data Set & Methodology & 5 C's Dimensions \\
\hline & $\begin{array}{l}\text { January } 2001 \text { to } \\
\text { November } 2008\end{array}$ & & \\
\hline Emel et al. (2003) & $\begin{array}{l}\text { Loan applications of } \\
82 \text { companies in a } \\
\text { Turkish commercial } \\
\text { bank }\end{array}$ & $\begin{array}{l}\text { DEA, Regression, } \\
\text { Discriminant } \\
\text { Analysis }\end{array}$ & Capacity \& capital \\
\hline Min and Lee (2008) & $\begin{array}{l}103 \text { actual } \\
\text { bankruptcy cases of } \\
\text { firms in Korea }\end{array}$ & $\begin{array}{l}\text { DEA, Regression, } \\
\text { Discriminant } \\
\text { Analysis }\end{array}$ & Capacity \& capital \\
\hline Zhang et al. (2013) & $\begin{array}{l}187 \text { Chinese high- } \\
\text { tech listed } \\
\text { companies }\end{array}$ & $\begin{array}{l}\text { Regression (Cox } \\
\text { Model) }\end{array}$ & $\begin{array}{l}\text { Character, capacity, } \\
\text { capital, condition \& } \\
\text { collacteral }\end{array}$ \\
\hline Ono et al. (2014) & $\begin{array}{l}\text { 819 SME } \\
\text { questionnaire results } \\
\text { from Japanese firm } \\
\text { bank database }\end{array}$ & Regression & $\begin{array}{l}\text { Character, capital, } \\
\text { condition, \& } \\
\text { collateral }\end{array}$ \\
\hline Altman et al. (2018) & $\begin{array}{l}\text { 14,420 Italian SMEs } \\
\text { which include } 520 \\
\text { defaulted firms }\end{array}$ & Logistic Regression & Capacity \& capital \\
\hline $\begin{array}{l}\text { Frame, Srinivasan, } \\
\& \text { Woosley (2001) }\end{array}$ & $\begin{array}{l}200 \text { largest U.S. } \\
\text { banking } \\
\text { organizations }\end{array}$ & $\begin{array}{l}\text { Cross-sectional } \\
\text { Regression }\end{array}$ & $\begin{array}{l}\text { Capacity \& } \\
\text { condition }\end{array}$ \\
\hline Hu \& Ansell (2006) & $\begin{array}{l}195 \text { well-performed } \\
\text { companies and } 51 \\
\text { distressed companies } \\
\text { in U.S. retail } \\
\text { industry from } 1994 \\
\text { to } 2002\end{array}$ & $\begin{array}{l}\text { Naïve Bayes, } \\
\text { Logistic Regression, } \\
\text { Recursive } \\
\text { Partitioning and } \\
\text { Artificial Neural } \\
\text { Network, and } \\
\text { Sequential Minimal } \\
\text { Optimization (SMO) }\end{array}$ & $\begin{array}{l}\text { Character, capacity, } \\
\text { capital, condition, \& } \\
\text { collateral }\end{array}$ \\
\hline $\begin{array}{l}\text { Limsombuchai, Gan, } \\
\text { \& Lee (2005) }\end{array}$ & $\begin{array}{l}14,383 \text { good loans } \\
\text { and } 2,177 \text { bad loans } \\
\text { of Bank of } \\
\text { Agriculture and } \\
\text { Agricultural } \\
\text { Cooperative } \\
\text { (BAAC), Thailand }\end{array}$ & $\begin{array}{l}\text { Logistic Regression } \\
\text { and Artificial Neural } \\
\text { Network (ANN) }\end{array}$ & $\begin{array}{l}\text { Character, capacity, } \\
\text { condition, \& } \\
\text { collateral }\end{array}$ \\
\hline $\begin{array}{l}\text { Ziari, Leatham, \& } \\
\text { Turvey (1995) }\end{array}$ & $\begin{array}{l}\text { Loan applications of } \\
\text { Canada's Farm } \\
\text { Credit Corporation } \\
\text { from 1981-1983 }\end{array}$ & $\begin{array}{l}\text { Discriminant } \\
\text { Analysis }\end{array}$ & Capacity \& capital \\
\hline $\begin{array}{l}\text { Ellinger, Splett, \& } \\
\text { Barry (1992) }\end{array}$ & $\begin{array}{l}87 \text { credit scoring } \\
\text { models of } \\
\text { agricultural banks in } \\
\text { U.S. }\end{array}$ & $\begin{array}{l}\text { Product-moment } \\
\text { correlation } \\
\text { coefficient and } \\
\text { Kendall tau and }\end{array}$ & $\begin{array}{l}\text { Character, capacity, } \\
\text { capital, \& collacteral }\end{array}$ \\
\hline
\end{tabular}


Volume 2 Issue 4 (September 2020) PP. 25-41

DOI 10.35631/AIJBAF.24003

\begin{tabular}{|c|c|c|c|}
\hline Author(s) & Data Set & Methodology & 5 C's Dimensions \\
\hline & & $\begin{array}{l}\text { Spearman } \\
\text { correlation } \\
\text { coefficients }\end{array}$ & \\
\hline $\begin{array}{l}\text { Barry \& Ellinger } \\
\text { (1989) }\end{array}$ & $\begin{array}{l}\text { St. Louis \& } \\
\text { Louisville Farm } \\
\text { Credit Banks } \\
\text { portfolios }\end{array}$ & $\begin{array}{l}\text { Multiperiod } \\
\text { Simulation Model }\end{array}$ & Capacity \\
\hline $\begin{array}{l}\text { Stover, Teas, \& } \\
\text { Gardner (1985) }\end{array}$ & $\begin{array}{l}44 \text { Agricultural } \\
\text { lending officers } \\
\text { from } 39 \text { midwestern } \\
\text { banks in U.S. }\end{array}$ & $\begin{array}{l}\text { Ordinary Least } \\
\text { Squares (OLS) } \\
\text { regression }\end{array}$ & $\begin{array}{l}\text { Character, capacity, } \\
\text { condition }\end{array}$ \\
\hline Ellinger et al. (1991) & $\begin{array}{l}734 \text { Agricultural } \\
\text { Banks in } 19 \text { States in } \\
\text { U.S. }\end{array}$ & $\begin{array}{l}\text { Qualitative analysis } \\
\text { using questionnaire }\end{array}$ & $\begin{array}{l}\text { Character, capacity, } \\
\text { capital, condition, \& } \\
\text { collateral }\end{array}$ \\
\hline $\begin{array}{l}\text { Bandyopadhyay } \\
\text { (2007) }\end{array}$ & $\begin{array}{l}\text { Data of } 900 \\
\text { borrowers in } \\
\text { agriculture sectors } \\
\text { who got financed by } \\
\text { a large Public Sector } \\
\text { bank in India from } \\
1992 \text { to } 2007\end{array}$ & Logistic Regression & $\begin{array}{l}\text { Character, capacity, } \\
\text { capital, condition, \& } \\
\text { collateral }\end{array}$ \\
\hline $\begin{array}{l}\text { Onyenucheya \& } \\
\text { Ukoha (2007) }\end{array}$ & $\begin{array}{l}90 \text { smallholders } \\
\text { agricultural loan } \\
\text { beneficiaries of } \\
\text { Nigerian } \\
\text { Agricultural } \\
\text { Cooperative and } \\
\text { Rural Development } \\
\text { Bank (NACRDB) }\end{array}$ & $\begin{array}{l}\text { Semi-log regression } \\
\text { model }\end{array}$ & $\begin{array}{l}\text { Character, capacity, } \\
\text { \& condition }\end{array}$ \\
\hline $\begin{array}{l}\text { Jouault, et. al. } \\
\text { (2011) }\end{array}$ & $\begin{array}{l}756 \text { loans from a } \\
\text { French Bank: CIC- } \\
\text { Banque SNVB }\end{array}$ & $\begin{array}{l}\text { Binomial logit } \\
\text { regression }\end{array}$ & $\begin{array}{l}\text { Capacity \& } \\
\text { collateral }\end{array}$ \\
\hline
\end{tabular}

\section{Conclusion}

Based on the discussion above, it can be concluded that there are five major aspects that should be involved in assessing credit risk quality of a borrower. The five major aspects are following the 5 C's of credit concept which comprises of character, capacity, capital, and collateral. Furthermore, in each major factor, there are derivations which construct the whole concept of 5 C's of credit. The findings of this research, as depicted in figure 5, can be used as a basic conceptual model for financial institutions or peer-to-peer lending to develop credit scorecard in assessing borrowers who propose productive loan. Furthermore, the finding of this research will also contribute to the increase of financial inclusivity in Indonesia. 


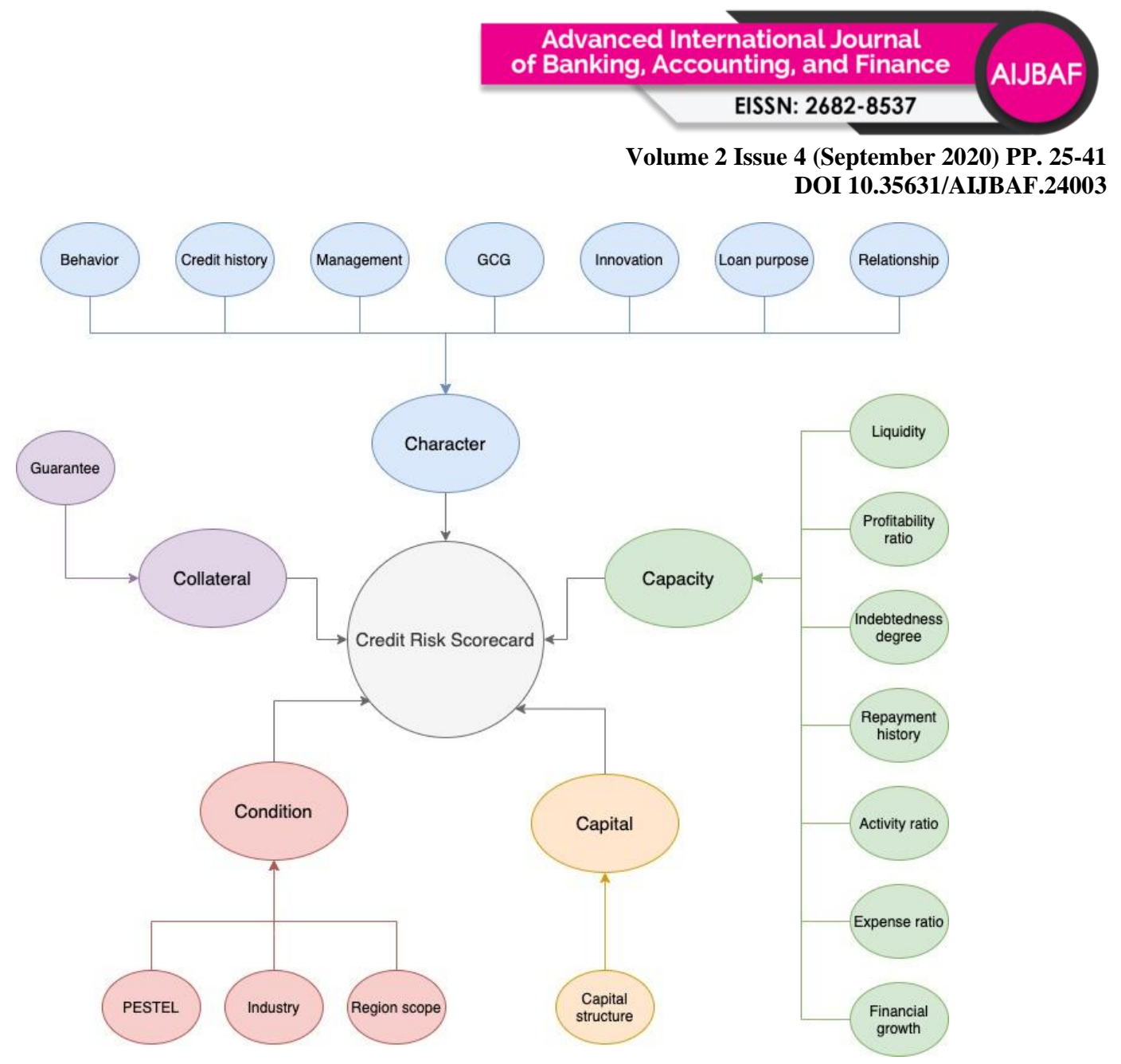

Figure 5. Research Conceptual Model. (Author's Analysis)

\section{References}

Altman, E. I., Esentato, M., \& Sabato, G. (2018). Assessing the credit worthiness of Italian SMEs and Mini-bond Issuers. Global Finance Journal, 10.1016/j.gfj.2018.09.003.

Amelie, J., \& Allen M., F. (2001). Determining the probability of default of agricultural loans in a French bank. Journal of Applied Finance \& Banking, ISSN 1792-6599, Vol. 1, Iss. 1, 1-30.

Badan Pusat Statistik. (2019, November 5). Sekretariat Kabinet Republik Indonesia. Retrieved from https://setkab.go.id: https://setkab.go.id/jumlah-orang-bekerja-naik-250-jutakepala-bps-dari-100-angkatan-kerja-terdapat-5-penganggur/

Baiden, J. (2011). The 5C's of credit in the lending industry. Accra: Central University College. Bandyopadhyay, A. (2007). Credit Risk Models for Managing Bank's Agricultural Loan Portfolio. MPRA Paper.

Bank Indonesia. (2015, June 25). Peraturan Bank Indonesia no. 17/11/PBI/2015 tentang Perubahan Atas Peraturan Bank Indonesia No. 15/15/PBI/2013 Tentang Giro Wajib Minimum Bank Umum Dalam Rupiah dan Valuta Asing bagi Bank Umum Konvensional. Retrieved from Bank Indonesia: https://www.bi.go.id/id/peraturan/ssk/Pages/pbi_171115.aspx

Bank Indonesia. (2020, March 28). Glossary. Retrieved from Bank Indonesia: https://www.bi.go.id/en/Kamus.aspx?id=N

Barry, P. J., \& Ellinger, P. N. (1989). Credit Scoring, Loan Pricing, and Farm Business Performances. Western Journal of Agricultural Economics 14(1), 45-55.

Bhatt, N. (2012). Financing of SMEs and Credit Risk: The Inevitable 5Cs. Journal of Commerce and Trade, 13-17. 
Budimir, T., \& Aralica, Z. (2013). Assessment of creditworthiness of crafts in croatia. The Sixth International Conference, 133-150.

Caracota, R. C., Dimitriu, M., \& Dinu, M.-R. (2010). Building a Scoring Model for Small and Medium Enterprises. Theoretical and Applied Economics, 117-128.

Castro, C., \& Garcia, K. (2014). Default risk in agricultural lending, the effects of commodity, price volatility, and climate. Agricultural Finance Review, 501-521.

Chen, D., Lai, F., \& Lin, Z. (2014). A trust model for online peer-to-peer lending: a lender's perspective. Springer.

Demirguc-Kunt, A., Klapper, L., Singer, D., Ansar, S., \& Hess, J. (2017). The Global Findex Databaase. Washington DC, United States of America: World Bank Group.

Donaldson, T. H. (1986). How to handle problem loans. New York: St. Martin's Press.

Ellinger, P. N., Splett, N. S., \& Barry, P. J. (1992). Consistency of Credit Evaluations at Agricultural Banks. Agribusiness 8(6), 517-536.

Ellinger, P., Splett, N., Barry, P., LaDue, E., Gustafson, C., Hanson, G., . . . Pederson, G. (1991). Credit Evaluation Procedures at Agricultural Banks. Regional Research Committee NC-161, 59-81.

Emel, A. B., Oral, M., Reisman, A., \& Yolalan, R. (2003). A credit scoring approach for the commercial banking sector. Socio-Economic Planning Sciences 37, 103-123.

Frame, W. S., Srinivasan, A., \& Woosley, L. (2001). The Effect of Credit Scoring or SmallBusiness Lending. Journal of Money, Credit and Banking 33(3), 813-825.

Gitman, L. J., \& Zhutter, C. J. (2012). Principles of Managerial Finance. Pearson Education.

Gool, J. V., Verbeke, W., Sercu, P., \& Baesens, B. (2011). Credit Scoring For Microfinance: Is It Worth It. International Journal of Finance and Economics.

Greenberg, M. S. (1980). A Theory of Indebtedness. In K. J. Gergen, M. S. Greenberg, \& R. H. Willis, Social Exchange (pp. 3-26). Boston, MA: Springer.

Hu, Y.-C., \& Ansell, J. (2007). Measuring retail company performance using credit scoring techniques. Journal of Operation Research 183, 1595-1606.

Jouault, A., \& Featherstone, A. M. (2011). Determining the Probability of Default of Agricultural Loans in a French Bank. Journal of Applied Finance \& Banking 1(1), 130 .

Kastner, M., Tricco, A. C., Soobiah, C., Erin, L., Perrier, L., Horsley, T., . . Straus, S. E. (2012). What is the most appropriate knowledge synthesis method to conduct a review? Protocol for a scoping review. BMC Medical Research Methodology 2012, 12:114, http://www.biomedcentral.com/1471-2288/12/114.

Komite Nasional Kebijakan Governance. (2006). Pedoman umum good corporate governance Indonesia. KNKG.

Limsombunchai, V., Gan, C., \& Lee, M. (2005). An Analysis of Credit Scoring for Agricultural Loans in Thailand. American Journal of Applied Sciences, 1198-1205.

Min, J. H., \& Lee, Y.-C. (2008). A practical approach to credit scoring. Expert System with Applications 35, 1762-1770.

Mittal, S., Gupta, P., \& Jain, K. (2011). Neural network credit scoring model for micro enterprise financing in India. Qualitative Research in Financial Markets Vol. 3 No. 3, 2011, 224-242.

Namvar, E. (2013). An introduction to peer-to-peer lending loans as investment.

OECD. (2015). G20/OECD Principles of Corporate Governance. Paris: OECD Publishing.

Ogler, Y. E. (1970). A Credit Scoring for Commercial Loans. Journal of Money, Credit \& Banking, 435-445. 
Ono, A., Hasumi, R., \& Hirata, H. (2014). Differentiated use of small business credit scoring by relationship lenders and transactional lenders: Evidence from firm-bank matched data in Japan. Journal of Banking \& Finance, 371-380.

Onyunecheya, F., \& Ukoha, O. O. (2007). Loan repayment and credit worthiness of farmers under the Nigerian Agricultural Cooperative and Rural Development Bank (NACRDB). Agricultural Journal, 265-270.

Orgler, Y. E. (1970). A Credit Scoring Model for Commercial Loans. Journal of Money, Credit and Banking 2(4), 435-445.

Otoritas Jasa Keuangan. (2016, December 29). POJK Nomor 77/POJK.01/2016. Retrieved from Otoritas Jasa Keuangan: https://www.ojk.go.id/id/regulasi/otoritas-jasakeuangan/peraturan-ojk/Pages/POJK-Nomor-77-POJK.01-2016.aspx

PwC Indonesia. (2019). Indonesia's Fintech Lending: Driving Economic Growth Through Financial Inclusion. PwC Indonesia.

Rosavina, M., Rahadi, R. A., Kitri, M. L., Nuraeni, S., \& Lidia, M. (2019). P2P lending adoption by SMEs in Indonesia. Qualitative Research in Financial Market, 260-279.

Rothaermel, F. T. (2019). Strategic Management. New York: McGraw Hill Education.

Saygili, E., Saygili, A. T., \& Isik, G. (2019). An analysis of factors affecting credit scoring performance in SMEs. EGE Academic Review, 159-172.

Sbârcea, I. R. (2008). Practical Approach to The Vision Over Credit Risk at the Level of A Commercial Bank in Romania. Identification of Credit Risk in A Credit Portfolio Granted for Agriculture. Romanian Economic and Business Review, 84-101.

Splett, N., Barry, P., LaDue, E., Ellinger, P., Gustafson, C., Hanson, G., . . . Pederson, G. (1992). Credit Evaluation Procedures at Agricultural Banks. Regional Research Committee NC-161, 59-81.

Stover, R. D., Teas, R. K., \& Gardner, R. J. (1985). Agricultural lending decision: A multiattribute analysis. American Agricultural Economics Association, 513-520.

Zenzerović, R. (2011). CREDIT SCORING MODELS IN ESTIMATING THE CREDITWORTHINESS OF SMALL AND MEDIUM AND BIG ENTERPRISES. Croatian Operational Research Review 2, 143-157.

Zhang, M., He, Y., \& Zhou, Z.-f. (2013). Study on the Influence Factors of High-tech Enterprise Credit Risk: Empirical Evidence from China's Listed Companies. Journal of Information Technology and Quantitative Management, 901-910.

Ziari, H. A., leatham, D. J., \& Turvey, C. G. (1994). Application of mathematical programming techniques in credit scoring of agricultural loans. North Central Regional Projejct NC207, 156-171. 